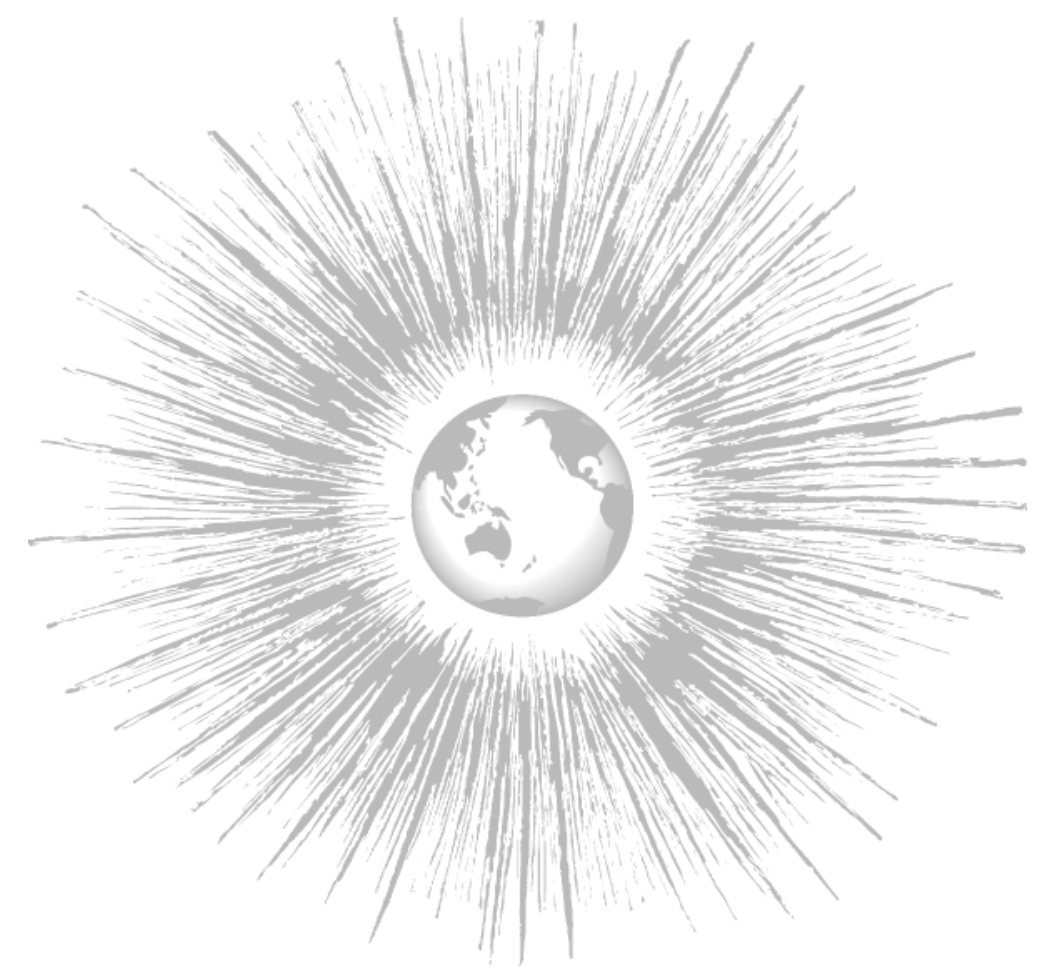

ABSTRACT:

This paper claims that, since many of the concepts relevant to our analysis of systemic change were coined in and about the core, the potential with which solutions to world systemic crisis are credited in the long run should be assessed differently depending on the structural location of their origin. In the periphery, such concepts as conservatism socialism and even liberalism took forms that often retained nothing of the original mode but the name, such that strategies of applying them to (semi)peripheral situations ranged from "stretching the ideology" to "discarding the (liberal) myth" altogether. In a first step "the hypothesis of semiperipheral development" (Chase-Dunn and Hall), according to which the semiperiphery represents the most likely locus of political, economical, and

\section{Semiperipheries in the World-System: Reflecting Eastern European and Latin American Experiences*}

\section{Manuela Boatcă}

\section{THE SOCIALIST EXPERIMENT(S) - ANTISYSTEMIC OR SYSTEM-PRESERVING?}

Tn terms of the potential for transformation with which it has been credited, the socialist solution to global inequality has been considered both among the most promising and among the most overrated political strategies of the past centuries. Especially after the concerted collapse of communist regimes in Eastern Europe and the allegedly definitive triumph of liberalism on a worldwide scale (Fukuyama 1992), the exhaustion of such potential became the political wisdom of the day. Scholarly attention accordingly shifted away from the competition within the formerly "bipolar" political system and toward an assessment of the postsocialist societies' chances of moving from the Second World into the First, i.e., of "catching up" with the advanced capitalist countries. Yet, against the backdrop of Eastern Europe's ever more clear Third-Worldization (Frank 1992:40ff,, Böröcz 1999:200), the negatively descriptive category of "postsocialism," still not satisfactorily replaced or updated fifteen years after

Manuela Boatcă

Katholische Universität Eichstätt-Ingolstadt

Lehrstuhl für Soziologie I

Ostenstr. 26, 85072 Eichstätt

Germany

manuela.boatca@ku-eichstaett.de

* This article goes back to a paper presented at the 29th Conference of the Political Economy of the World-System (PEWs), University of Massachusetts at Amherst, April I4-I5, 2005. A shorter version endorsing the same argument while emphasizing the political aspect is forthcoming in: Joya Misra and Agustín LaoMontes (eds.): The State Under Neoliberal Globalization, Paradigm Press: Boulder and London, 2007. I thank Tom D. Hall, Agustín Lao-Montes, Joya Misra, and the anonymous reviewer for their comments and critique on earlier drafts of this paper.

JOURNAL OF WORLD-SYSTEMS RESEARCH, XII, II, DECEMBER 2006, 32I-346

http://www.jwsr.org/

ISSN $1076-156 \mathrm{X}$

(c) 2006 Manuela Boatcă 
the regime change, loses more of its explanatory value every day, as the region's attractiveness for mainstream social science is dwindling.

From a world-systems perspective, on the other hand, socialism was a political structure used by semiperipheral nations in order to adapt to stage four in the evolution of the modern world-system - the "consolidation" of the industrial capitalist world-economy (Wallerstein 2000:97). As in the case of the Russian Revolution of 1917, which marked the beginning of that stage, the emergence of socialist states was seen as an instance of the classic mercantilist technique of semi-withdrawal from the world economy intended to stem a decline towards a peripheral status. The availability of core elements at the moment of "socialist revolutions," Wallerstein pointed out, had made it much more likely for such a path to be chosen by Russia, China, and Cuba than by Thailand, Liberia, or Paraguay - that is, by peripheral countries lacking both the manufacturing beginnings and the skilled personnel necessary for the successful application of a mercantilist strategy (Wallerstein 2000:Ioo). Thus, world-systems analysts contend that through the allocation of a larger share of the world economic surplus, the socialist states had contributed to depolarizing the capitalist system and had therefore consolidated - not undermined it — as the Cold War ideology implied. More important than on the economic level, however, was the equally stabilizing function they performed on the political level (Wallerstein 2000:9I). By preventing the unified opposition of all non-core areas against the upper stratum, the emergence of socialist countries as a middle stratum-both agent of and subject to exploitation - had filled the required intermediate slot by which semiperipheral states, regardless of their economic roles, had ensured the survival of the modern world-system since its inception. Hence, while their economic function remains significant for the system's operativeness, it is primarily the political task that accounts for differences among semiperipheral countries. ${ }^{1}$ To world-systems analysts, then, the collapse of Eastern European communist regimes 1989 through 199I, rather than heralding the triumph of liberalism as the systems' leading geoculture, had actually underscored the increasing lack of legitimacy of both liberalism and Marxism as the system's ideological underpinnings (Wallerstein I99ib:2).

1. "The essential difference between the semiperipheral country that is Brazil or South Africa today and the semiperipheral country that is North Korea or Czechoslovakia is probably less in the economic role each plays in the worldeconomy than in the political role each plays in conflicts among core countries" (Wallerstein I979:75).

\section{THE TRANSFORMATIVE POTENTIAL OF SEMIPERIPHERIES}

Comparative world-systems studies later built and expanded on this particular case with a view to providing an explanation of fundamental transformations in systemic logic in the long run. According to the "hypothesis of semiperipheral development" (Chase-Dunn 1988:31), both system structures and modes of accumulation are often transformed as a result of institutional and organizational changes occurring in semiperipheral areas. On account of being the most likely location in which social, institutional and technological innovation, new centers of resource control, and transformational actors will first emerge in the system, the structural position of the semiperiphery as such therefore comes with "developmental (or evolutionary) significance" (Chase-Dunn and Hall 1997a:79). This is not only true of previous world-systems, but also of the modern one, all of whose successive hegemons-the Netherlands in the seventeenth century, Great Britain in the nineteenth, the United States in the twentieth-have previously been semiperipheral states (Chase-Dunn and Hall $1997 b \div 432$ ). More importantly still, "the rise of the West" to the core of the modern world-system can be reasonably interpreted as an instance of semiperipheral development within the larger Afroeurasian system of the fifteenth century (Chase-Dunn and Hall i997b:408).

The logic behind this argument rests on a twofold premise: on the one hand, as regions located between competing core and peripheral zones, mixing both core and peripheral organizational forms, and displaying institutional features halfway between those in the (proximate) core and those in the (proximate) periphery (Chase-Dunn and Hall I997a $\$ 8$, Chase-Dunn 2005), semiperipheral areas enjoy what has been variously theorized ${ }^{2}$ as the "privilege of historic backwardness" (Trotsky 1932:4). Access to the latest technologies, unencumbered, however, by the costs of empire, as well as a lesser vulnerability to combined attack from core competitors (Chase-Dunn and Hall $1997 \mathrm{~b} \div 414$ ) foster a condi-

2. Systematically dealt with for the first time within evolutionary cultural anthropology (Sahlins and Service 1960), the innovative potential inherent in a region's lack of specialization and the greater developmental success resulting from it had been previously theorized with respect to the "late industrializers" in terms of the "advantage of backwardness" (Gerschenkron 1966) or the "merits of borrowing" from an alreadyindustrialized neighbor (Veblen 1915, in: Sahlins and Service 1960:99) allowing latecomers to "skip stages" of their predecessors' industrial evolution (Trotsky 1932:4). The different wording notwithstanding, Chase-Dunn and Hall (I997a:82) consider these and other related approaches as akin to their own view that a semiperipheral location is a fruitful locus of transformational changes. 
tion allowing intermediate areas to develop an increasing comparative advantage relative to the core and gradually come to dominate the system.

On the other hand, the semiperiphery's intermediate structural position in the world-system provides the best-suited ground for successful antisystemic movements. While core exploitation of the periphery accounts for the formation of a large middle-class segment and of a labor aristocracy in the core, both of which have habitually acted to the detriment of political polarization, class struggle in the periphery has either been suppressed by core intervention or has taken a back seat in favor of nationalist class alliances against the core (Chase-Dunn 200I:606). By contrast, the semiperiphery has enjoyed the particular condition arising from the "double antinomy of class (bourgeois-proletarian) and function in the division of labor (core-periphery)" (Wallerstein 1979:96f.) inherent to this structural position. As a result, both its liberation movements and its socialist revolutions have gained from the conflicting interests of semiperipheral elites and masses, and have accordingly been more class-based and more militant in character than either in the core or the periphery-a luxury they could afford not least due to the availability of relative economic and military strength needed in order to counter retaliation on the part of the core. Hence, in this view, the establishment of communist regimes in the semiperiphery and the strong antisystemic challenge they posed to core capitalism in terms of providing an oppositional ideology, transforming the dominant mode of accumulation, and limiting the mobility of capital (Chase-Dunn 2001:604) stand proof of the transformative potential of such intermediate positions in the structural hierarchy. Together with the fact that previous semiperipheral locations of other revolutionary movements and political struggles, such as Mexico, Brazil, or India, resurface today as sites of organizational innovation with great transformative capacity, ${ }^{3}$ this seems to indicate a pattern of structural continuity in semiperiphery-based antisystemic strategies (Chase-Dunn 2001:602). In terms of the analysis of current antisystemic movements and the projection of future trends, therefore, the acknowledgment of such continuities entails that substantiated knowledge of the context and dynamics of earlier struggles and the theoretical approaches in which they were anchored acquires momentous relevance for a proper understanding of possible counter-hegemonic scenarios and their political consequences.

3. For an analysis of the radicalization of protest in response to new forms of dependency in today's Brazil, see Schwartzmann 2004; for several case studies concerning the new coalitions between civil society actors protesting the activities of multinational corporations in India, see Randeria 2003.
Drawing on this position, this article will contend that, in the late modern world-system, the semiperiphery ${ }^{4}$ remains a relevant locus of long-term social change, whose strength however now predominantly resides in the cultural and epistemic sphere. Using examples of major challenges that semiperipheral actors in Eastern Europe and Latin America have posed to the world-system's political fields and institutional settings both in the past and to date, it will be argued that a comparative analysis of continuities among political epistemologies developed in the semiperiphery can help us understand the ways in which similar attempts can become antisystemic today.

That the very structural position meant to ensure both the political and the economic stability of the world-system should at the same time perform the very opposite function - that of generating antisystemic strategies-is paradoxical at first glance. If the very causal explanation accounting for the development of the system by means of hegemonic cycles is also meant to account for its demise, the logical question to be asked is why haven't semiperipheral transformations proven antisystemic during previous hegemonic sequences? In order to provide an answer, a further dimension of semiperiphery-based change has to be factored in.

\section{SEMIPERIPHERY REVISITED: THE EPISTEMOLOGICAL DIMENSION OF} TRANSFORMATIVE PROCESSES

In the capitalist world-economy, counter-hegemonic ideologies rooted in a different cultural background than that of the dominant core have constituted a frequent means of challenging core power from semiperipheral locations. To this effect, Chase-Dunn and Hall mention both Protestantism-as a religion of the semiperiphery that democratized access to the deity and undermined Spain's religious and political authority in the process (Chase-Dunn and Hall 1997a:94) - and the equally semiperipheral communism-as a funda-

4. The concept of "semiperiphery" as discussed here follows the treatment given it by Wallerstein (1979), Chase-Dunn (I988), Arrighi and Drangel (I986). I agree with Burns et al. (1997) and Terlouw (1993) that the term is undertheorized relative to the notions of "core" and "periphery" and that further subdivisions within the semiperiphery would help account for the widely different levels of economic, political, technological and military strength of countries counting as semiperipheral. For the purposes of the present argument, however, the distinction between the "semicore" and the "semiperiphery" proposed by Kick (1987) and Burns et al. (1997) is however deemed inadequate for helping to explain the task of all intermediate positions of absorbing and/or resolving tensions between the core and the periphery. 
mentally oppositional ideology that, at least in principle, called into question the capitalist logic of ceaseless accumulation. They however consider both to be merely types of institutional innovations. Yet for semiperipheral areas to be able to generate new institutional forms capable of transforming both system structures and modes of production, as this perspective suggests, the search for the particular operative rationale on which these forms are based has to be prompted by a different cultural and epistemic logic-one that, as Walter Mignolo has put it, changes the terms, not just the content of the conversation (Mignolo 2000:16). It thus follows that antisystemic initiatives emanating from today's semiperipheries tend to operate less on the mere institutional and/or state level and rely instead on transforming the world-system's geopolitical imaginary by advancing new epistemological perspectives. Hence, while semiperipheral locations have no doubt produced a disproportionate share of significant economic, political and organizational advance, the most promising challenges to the capitalist logic currently consist in the critical utopias being developed within the World Social Forum (a process initiated and consolidated in the Brazilian semiperiphery and gradually expanding into other semiperipheral areas) (Quijano 2002, Santos 2004) or inherent in theoretical revolutions such as the one advanced by the Zapatistas (in the Mexican semiperiphery) (Mignolo 2002). It can thus reasonably be argued that the tension between the stabilizing and the counter-hegemonic functions of semiperipheries belongs to the series of internal contradictions that, according to the logic Wallerstein has identified for all historical systems in general and the modern world-system in particular, are exacerbated by the secular trends to the point of bringing about the system's demise (Wallerstein 1991b:24f.). In the case of the semiperipheries, this translates as saying that, in the course of the system's evolution, their transformative potential has gone from providing a stimulus for upward mobility (challenging the core's hegemony) to engendering antisystemic strategies. As such, the extension of the "hypothesis of semiperipheral development" into the cultural-epistemological realm does not contradict the view according to which the semiperiphery is "the weak link" in the capitalist world-system (Chase-Dunn 2001:606, Chase-Dunn 2005:174) - it merely amends it by an additional-yet crucial-dimension.

\section{Competing for a Voice: Non-Core Attempts at Shaping the System's Political Imaginary}

From a postcolonial point of view, the present-day structural positions of core and periphery not only mirror economic and political tasks within the international division of labor, but also the epistemological divides between "developed" and "underdeveloped" societies which the Eurocentric perspective of knowledge accompanying the "rise of the West" helped put in place as of the $16^{\text {th }}$ century. Accordingly, the expansion of the capitalist world-economy went hand in hand with the production of truth claims about the newly colonized areas intended to legitimize the system's basic logic: "The construction of 'pathological' regions in the periphery as opposed to the so-called 'normal' development patterns of the 'West' justified an even more intense political and economic intervention from imperial powers. By treating the 'Other' as 'underdeveloped,' as 'backward', metropolitan exploitation and domination were justified in the name of the 'civilizing mission'" (Grosfoguel 2000:370). The peripheral areas' acceptance or even internalization of the system's successive "global designs" (Mignolo 2000) - whether Christianization, the civilizing mission, Marxism, or neoliberalism - amounted to a "silencing" in terms of the production of knowledge, thereafter defined and controlled from the local histories of Western Europe (and North America).

By contrast, intermediate world-systems positions have in this respect been subjected to the same contradictory yet stimulating tendencies that characterize their social and economic development. Historically, this has meant benefiting from two conditions: first, not being the core entailed experiencing situations of political and economic domination akin to the ones in peripheral areas and facing the need to develop theoretical and practical solutions to them. Second, not being the periphery amounted to a certain degree of visibility in the production of knowledge, which intellectual projects in the "silenced societies" of peripheral areas did not enjoy. The discursive practices of the core easily illustrate the different epistemological standing of the semiperiphery to that effect: unlike the peripheral Orient, which was constructed as an incomplete Other of Europe and as the locus of barbarism, irrationality, and mysticism (Said I994:49ff.), the semiperipheral Balkans, to which too many of the attributes that had gone into the construction of the (white, Christian, European) Western self were undeniable, have featured in the Western imaginary rather as Europe's incomplete Self (Todorova 1997:18) since at least the nineteenth century. Geographically European (by $20^{\text {th }}$ century standards, at any rate), yet culturally alien by definition, the Balkans, as the Orient, have conveniently absorbed massive political, ideological and cultural tensions inherent to the regions outside the Balkans, thus exempting the West from charges of racism, colonialism, Eurocentrism and Christian intolerance while serving "as a repository of negative characteristics against which a positive and self-congratulatory image of Europe and the 'West' has been constructed" (Todorova 1997:60).

Similarly, and at approximately the same time, "Latin" America as an explicit political project of imperial France and, later, of Creole elites in the 
former Spanish and Portuguese colonies of the Americas started playing the role of a new racial category, primarily defined by its marginal status with respect to Europeans and North Americans, rather than by blood descent and skin color (Mignolo 2005:73, Wallerstein 2005a:32). Until World War II, the difference attributed to the region with regard to the West was, as in the case of Eastern Europe, more one of degree than one of substance: "although 'Latin' American Creoles and elite Mestizos/as considered themselves White, particularly in relation to the Indian and the Afro population..., from the perspective of Northern Europe and the US, to be 'Latin' American was still not to be White enough" (Mignolo 2005:90). By being gradually associated with those racial, cultural, and temporal attributes that had acquired a negative connotation in the context of the self-definition of the modern West-non-White, Catholic, and underdeveloped- "Latin America" served in particular as an asymmetric counterconcept for North America in the Occidental construction of Otherness (Feres 2003, 2005).

The fact that this discursive (mal)treatment should apply to South America and East-Central Europe, whose early incorporation into the modern worldsystem as areas of coerced labor has made them into "the first large-scale laboratories of underdevelopment" (Szlajfer 1990:I) is therefore no coincidence. While the structural similarities between the two regions in terms of their imputed "backwardness" are sometimes acknowledged as causes for the emergence of their respective "second serfdoms" (Malowist 1966, Stahl 1993, Wolf 200I), their similar theoretical strategies for the conceptualization of this condition-themselves structural responses to that socioeconomic situation-are rarely perceived as such. The reason, as will be suggested in the following, lies not only in the different timing at which the concerns were voiced in the two locations - starting in the late $19^{\text {th }}$ century for Eastern Europe and in mid-20 $\mathrm{O}^{\text {th }}$ century for Latin America-but also, and more importantly, in the dissimilar opportunity structure for making these theoretical strategies visible beyond regional (or even state) borders.

Given the close link between structural location and valid theoretical production in the logic of Western modernity, the intellectual division of labor among world-system positions places theory, together with civilization and culture, in the core, while consigning the periphery to an object of study of the former and thus to the status of "silenced societies" in terms of the production of knowledge (Mignolo 2000:73, Mignolo 2005:109). Accordingly, at the same time that awareness of peripheral conditions was enhanced in most semiperipheral areas by their own previous experience of peripherality, the knowledge thus produced only obtained a hearing within Western cultures of scholarship once the respective areas ascended into intermediate positions in the world-system.
Thus, the radical theoretical challenge which dependency theory and liberation philosophy posed to the hegemonic idea of Latin America in the 1960s (Mignolo 2005:9I; I09) owed a significant share of its success to the fact that, at the moment of its emergence, most states in the region had either already attained semiperipheral status or were well on their way to it. From this position of midrange visibility and power it was possible to advance a dissenting approach to development as a legitimate Third World response to the post-war world order (Mignolo 2000:54) for which the modernization school advocated a one-sizefits-all solution. By rejecting the dominant view of underdevelopment as a "stage" previous to development, and instead conceptualizing it as a "discrete historical process through which economies that have already achieved a high level of development have not necessarily passed" (Furtado 1964:129), dependency theorists for the first time denounced the core's explanation for economic backwardness and the corresponding "catching up" imperative for newly independent nations as "ideology disguised as science" (Dos Santos 1971:236). Against this background, the phrase "development of underdevelopment" (Frank 1966), meant to highlight what dependency theorists viewed as the essential connection between the industrialization of the core and the economic specialization of the periphery on staple agricultural production, not only came to stand for the dependency perspective as such, but also for one of the most successful epistemological shifts in the conceptualization of social change.

\section{Political Epistemologies in Turn-of-the-Century Romania}

In contrast, an equally dissident theoretical corpus dealing with the development of underdevelopment in the periphery and elaborated in Romania ${ }^{5}$ at the end of the $19^{\text {th }}$ and the beginning of the $20^{\text {th }}$ centuries never did obtain international hearing. In this case, the context of the country's recent political independence from the Ottoman Empire and renewed peripheralization as Western Europe's agrarian province made for the accidental geohistorical "edge" (Wallerstein 2000:89) usually considered decisive for a state's initial eligibility for a particular structural position in the world-system. The economic

5. The three Romanian Principalities, Transylvania, Wallachia, and Moldavia, briefly reunited in 1600 , only achieved political unity again in 1918. Because the theories to be discussed in the following were meant to apply to the development of all three provinces, the unification of which had been a long-standing political goal, reference is made to "Romania" in the remainder of this article. For a discussion of the intellectual debates of the Igth and 20 th centuries in the context of the struggle for political unity, see Boatcă 2003. 
and political peripheralization was therefore completed on the epistemological level by silencing the critical theories developed in the area ${ }^{6}$ and thus dampening their antisystemic potential. This was all the easier in view of Romania's solitary position with respect to the theoretization of backwardness within Eastern Europe at that time. While economic and political elites in late $18^{\text {th }}$ and early $19^{\text {th }}$ century Poland had diagnosed their country's underdevelopment as a problem and had employed innovative economic ideas and measures in order to combat it, it wasn't until after World War II that a critical awareness of underdevelopment crystallized in the region (Szlajfer 1990:3), as it would in Latin America. The dependentistas' socialist solution to the structural underdevelopment of Third World countries, conceived as a response to the uniformizing tendencies advocated by modernization theory in the 1960s, would amount to an opting out of the international division of labor. In turn, the Romanian theorists of the late nineteenth century, faced with a period of interregnum or with what has been called "the shift of peripheral axis" (Bădescu 2004:82ff.) from the periphery of the Ottoman Empire to that of the Western core, were more concerned with controlling the degree of self-determination that incorporation into the world-system entailed. Theirs was therefore a search for a modernization process tailored to the country's specific needs and the solutions offered covered a wide range of options and political stances with potential for systemic change.

Their starting point was the "theory of forms without substance," elaborated in 1868 by the conservative Titu Maiorescu (1840-1917). As a result of the economic and cultural opening toward the West, Romania's liberal government of the time had encouraged the adoption of Western laws and institutional structures thought to stimulate a corresponding level of development. Yet, given the country's position at the crossroads between three empires-the AustroHungarian, the Tsarist, and the Ottoman one-the thorough social change the imported cultural forms induced, Maiorescu warned, instead endangered state sovereignty. A peasant country like Romania, he argued, had not been prepared by anything in its history to receive all the "outer forms" of civilization in the absence of "the deeper historical foundations which with necessity produced"

6. World-systems theorists were the first to draw attention to the precursory character of the early 20 th century Romanian theories for the analysis of underdevelopment (Chirot 1978, Stahl 1978). With few exceptions (see Love 1996), the theories' treatment within the larger context of social scientific approaches to underdevelopment however remained marginal.
(Maiorescu 1973a:164) them and it lacked the means to support them-industrial production and a middle class. Contrary to the liberals' claims, imported superstructural forms did not foster progress, but only concealed the power structures inherent in the relationship between Western and Eastern Europe (Maiorescu 1973b:239), the better to exploit the latter. The costs of "modernization," Maiorescu noted one century in advance of the dependentistas, can only be assessed by considering both terms of the relationship, not by mandating modernity in self-contained societies. Consequently, Romania's sole possibility of preserving national independence throughout the process of modernization and of realizing her evolutionary potential depended on her providing a specific-cultural, economic, and political-foundation to match and sustain the adopted forms.

Suspicious of the liberals' firm belief in progress as mankind's universal law and in civilization as a superior stage of social evolution, the conservative Maiorescu instead emphasized organicity, gradual change, and the need for critical rethinking of wholesale cultural imports. With the help of this "double critique" - that he undertook from within modernity as a conservative, but from its outside as an intellectual of the system's periphery-Maiorescu laid the groundwork for viewing the borderline between the Western core and the Eastern European periphery as a new locus of enunciation of radically different solutions to social and political change.

In the course of the intellectual debates his theory engendered in the decades that followed, the classical political doctrines associated with the contenders' main ideological positions-themselves imported cultural formsexperienced a substantial reinterpretation in accordance with the peripheral status for which they were meant to account. Such attempts to fit political and socioeconomic writings into Western ideological categories, however, have constantly led to misconceptions about most critical knowledge produced in this and other non-core societies. While the "gigantic liberal-Marxist consensus" (Wallerstein I991b:I82) in the core postulated that peripheral development was to be induced by replicating Western development in backward countries on a "stage-by-stage" basis, the conservatives' departure from this model consisted only in viewing such replication as undesirable, not in questioning its results (Wallerstein I991b:55). In constrast, the periphery as an epistemological point of departure presupposed the filtering of the Western ideological notions through the perspective of the national concerns imposed by a geopolitical and historical context that differed from the one on which the political ideologies of the core had been tailored. Given the politically dependent status of most other nations in the region until 1918, these concerns only became apparent as national problems only after independence. This explains why, before that date, the state, 
local economic interests, and the encroachment of foreign capital upon both were contextualized rather within the frame of Russian, Austro-Hungarian and German nationalism in Poland, Hungary, Slovenia, the Czech lands, the Baltic states, and Ukraine (Szlajfer 1990:83).

In Romania, efforts of applying political doctrines of (and about) the core to the development of the periphery ranged from "stretching" the classical liberal doctrine by declaring the anomalies exceptional to "discarding" it altogether as a myth (see Boatcă 2003:120). While both will be addressed in the following, it is especially in this second set of solutions that the main contribution of the Romanian debates to the transformation of the Eurocentric systemic rationality resides.

\section{Translating the Periphery in Liberal Terms}

The liberal response with which the historian and economist Alexandru Xenopol (1847-1920) counteracted Maiorescu's theory illustrated the first of the two strategies. Although he, much like Maiorescu, pressed for specific instead of universalist solutions to development and viewed the economic specialization of agrarian countries as a danger to their state independence, Xenopol argued that all progress took place from forms to substance and that the import of liberal principles was inherently progressive. At the same time, he diagnosed the dependency of small, underdeveloped countries on industrial nations as a structural problem the cause of which he identified in the unequal exchange between the Western European industrialized core and its agrarian suppliers in the periphery. Free trade, he contended, was a means of exploitation, and the international division of labor the organizational structure within which it was promoted. Moreover, the peripheral countries' reliance on unskilled and hence cheap agricultural labor prompted the emergence of a non-productive middle class in the service of the State-itself, according to Xenopol, the biggest consumer-thus additionally saddling the peasant masses. By yielding a middle class made up of functionaries and "professionals," the dependent economic context gave rise to an internal division of labor that was in itself no longer self-sustaining, let alone capable of generating profit. Xenopol viewed unequal exchange, his country's economic dependency, as well as the changes wrought in its class structure by the export-oriented economy as the aggregated result of the free trade policy maintained by the State and advocated by the industrialized countries. The Western countries themselves, however, had not become rich by practicing free trade, he noted. Quite the contrary, it was during mercantilism, a time of government intervention, that their economies had experienced the most significant growth. The dominant anti-protectionist stance of his time, then, could not be supported historically, but had an ideological character motivated by the core countries' (by which the economist chiefly meant England and France) own economic interests. It was, in his words "theory at the service of a practice" (Xenopol I882:95).

Xenopol therefore suggested that Romania should discard the free trade policy advocated by the West, which only served Western economic interests, and instead adopt protectionism, promote large-scale industry, and rely on state investment. Paradoxically, this was in his view the task of the liberal government, whose policy-adapted to the needs of a peripheral country-Xenopol dubbed "new liberalism":

Until now, we have been ideologues; we used to think that wealth and wellbeing could result from theoretical creations. We were only concerned with laws which changed the outer form of our institutions, without trying to transform the very substance of our life. (Xenopol I882:126)

Consequently, Xenopol saw it as his duty to "dislodge the ideologies" of sociological theories. The concrete form this took, in his case, involved the search for a strategy of national development, since the situation of cultural and economic backwardness that he described was important to the extent that it was a national issue.

The first step in the transition from ideology to science accordingly consisted in abandoning the claim to a universal science and to corresponding universal principles of economic development such as those inherent in classic liberalism's doctrine of laissez faire. Instead of an individual party policy, "new" liberalism should become a state platform and as such take responsibility for inducing development and promoting industrialization. The issue of industrialization itself, more than just a good illustration of the periphery's general evolutionary potential, was "not only a question of gain, but one of civilization, ...not one of gain, but one of nationality" (Xenopol I882:86), and as such stood in close connection with a liberating economic and political course: "... crying out for liberty in a plainly agricultural country is in vain, for liberty is only possible where there are free people, and free people only exist in a country in which industry plays a significant role" (Xenopol I882:83). The "people," in this understanding, constituted the unit of progress at the national level, in which national ethnicity (as an intermediate human nature in between the individual and mankind) was articulated. Work enhancement at the level of the national economy and in international exchanges, capable of increasing the people's well-being as well as

\footnotetext{
7. Emphasis in the original
} 
of justly distributing it, accordingly represented the right national strategy that the "new liberalism" was supposed to implement.

Obviously, theorizing from within the concrete economic and social realities to which Xenopol's stance represented a response was hardly compatible with political impartiality. Consequently, his efforts of "dislodging ideologies" had to confine themselves to exposing the core's global designs as an expression of the local histories of Western societies, while at the same time providing as alternative an ideology suited to the local history of his own locus of enunciation. In this particular case, this meant a departure from Western liberalism in favor of a kind of national or state liberalism, more appropriate for the economic imperatives of peripheral development. In the process, Xenopol anticipated major concerns of both dependency theory and world-systems analysis, such as the ideological character of Western policies of development, the issue of unequal exchange, or the role of growing state bureaucracies in weakening the political and economic agency of the periphery (see Boatcă 2003:126-135).

\section{Peripheral Evolution - The Marxist Bent}

The amount of "stretching" that the socialist doctrine had to undergo before fitting a peripheral pattern of development was even greater than in the case of liberalism. In the course of recurrent polemics with the Conservatives' view of organic social evolution, the most prominent Romanian socialist, Constantin Dobrogeanu-Gherea (1855-1920), accounted for the discrepancy between Romania's economic substance and her political and cultural forms by claiming that it constituted a common trait of so-called "semicapitalist countries" on their way to attaining "full capitalism" (Gherea 1908b:459). While attesting to a teleological understanding of social development, his categorization into semicapitalist (or "backward capitalist") and capitalist societies clearly also allowed for divergent evolutionary paths, in that it declared the apparent idiosyncrasies Romania displayed in its transition to capitalism to be a common trait of peripheral regions, and as such consistent with the rule, not exceptions to it. It is on this basis that Gherea would consequently attempt to substantiate his "master idea"-rendering Romanian social history comprehensible by viewing it as an integral part of the expanding capitalist world-system-or, in his terms, of a "superior social organism" operating within "the historical capitalist epoch" (Gherea 1908a:483). According to the "law of the historical epoch" he formulated in 1908, it was the "bourgeois capitalism" of advanced industrial countries which imposed specific superstructural forms on the backward areas it targeted as new markets for its manufactured products:

Backward countries enter the orbit of advanced capitalist ones, they move within the orbit of those countries and their whole life, development and social move- ment are determined by the historical epoch in which we are living, by the bourgeois capitalist epoch. And this determination of the life and social movement of backward countries by the advanced ones is their very condition of life. ${ }^{8}$ (Gherea I908a:48I)

In terms of modifying the classical socialist doctrine in accordance with the social reality of the Eastern European periphery, Gherea's formulation implied that the essentially economic causes of transition to a new mode of production predominantly occasioned superstructural (i.e., social and institutional) transformations in "less advanced" countries. In turn, his generalization of this rule to all peripheral countries still undergoing capitalist "transition" yielded the exact reverse of what Marxism had propounded, despite Gherea's claim that it could be subsumed to the general principle:

In backward countries, the transformation of social life forms, of juridical, political, social forms, occurs...before the development of that socio-economic basis which in advanced countries made possible or even created those political and juridical social forms....In capitalist countries, social forms follow after the social substance, in backward countries, it is the social substance which follows after the social form. (Gherea I968:257f.)

The "new" form of organization of agricultural production that, following the comprehensive land reform of 1864 , had legalized coerced work in the form of labor contracts, Gherea claimed, represented the direct consequence of Romania's incorporation into the world division of labor, not a return to feudal relations of production. It had, however, proven disastrous to the national economy, as the state started deliberately employing this form of labor controlwhich Gherea (I9I0) accordingly labeled "neoserfdom"-in order to finance the consumerist habits of its growing bureaucracy. Not only had the so-called "democratic-bourgeois" state become the biggest consumer, as Xenopol had noted, but it also deliberately employed the neoserf regime as a means to the primary end of a production oriented toward consumerism and squander: "Yet the capital of large property does not face a capitalist form of labor, free wage labor,... but actually serf labor under the guise of contractual, coerced labor. Thus, we possess a double economical agrarian regime, an extraordinary regime: capitalist on the one hand, serf-based on the other..., whose existence for half a century is due only to the extraordinary advantages it holds for our economically dominant class" (Gherea 1910:95). ${ }^{9}$ Gherea's description of Romanian "neoserfdom" as a new form of labor control established as a result of the capitalist penetration

8. Emphasis in the original

9. Emphases in the original 
of Romania's economy, while different from Engels' "second serfdom," prefigured Wallerstein's conceptualization of "coerced cash-crop labor" as an alternative mode of labor control in those regions in which wage labor is less profitable for the world-economy as a whole. ${ }^{10}$

While he expected that socialism, too, would be brought to Romania from the outside in the context of the next historical epoch, Gherea also urged for a development policy that acknowledged the specificity of Romania's agrarian issue and the social ills derived from it to the country's structural position in the world-system's hierarchy. He therefore pleaded for a liberal solution that included industrialization, the adoption of universal suffrage, and the replacement of feudal "remnants" by "true" capitalist relations of production, which he viewed as a means to hasten the transition to full capitalism and to prepare the objective and subjective conditions for socialism.

No doubt the doctrinary and determinist form which Gherea's theory took-as in Xenopol's case, an instance of "stretching the (socialist) ideology,"-was the expression of the same developmentalist philosophy underlying the civilizing mission that had prompted the Romanian intellectuals' critical reactions in the first place. The most innovative aspects of his theory, however, came precisely from applying that critical spirit by consciously theorizing across ideological commitments from and about the periphery.

\section{Poporanism - A Politics for Agrarian Peripheries}

The centrality of the peasant issue eventually made the testing ground on the basis of which the major Western political doctrines were discarded as inadequate for the agricultural periphery. Constantin Stere (1865-1936), founder of a cultural and political program whose label, poporanism, attested to its focus on "the people" (Romanian popor), maintained that internationalist doctrines such as Western liberalism and social democracy could not account for the national problem faced by a small, economically and culturally backward agrarian state situated between three military powers: "In its exceptional situation, the Romanian people cannot pursue any revolutionary policy, nor aspire to the transformation of the very bases of social organization before the happier nations of the West. It still has to fight for its very national being, endangered both by its international situation... and by an abnormal social structure... which hinders the healthy development of national middle classes" (Stere 1996:208).

10. for a discussion of the differences and similitudes between Gherea's, Engels' and Wallerstein's approach, see Stahl I993: I07, Love I996: 38, Boatcă 2003: I8of., Boatcă $2005 \div 13$
Since, in purely agrarian countries such as Romania, it was the peasantry, not the proletariat, which overwhelmingly represented the working class, as Stere demonstrated with the help of statistical data, political significance was accordingly devolved to this social category. The peasant class of agricultural peripheries could therefore no longer assume the passive political role that its counterpart played in industrial countries. Stere thus openly confronted Gherea by maintaining that, instead of awaiting European social transformation, agrarian nations had to devise a path to social progress based on their specific socioeconomic problem - the peasant question — and on the corresponding political potential available to them (Stere 1996:183).

In a deliberate delimitation from both the "new liberal" and the "peripheral socialist" solutions that Xenopol and Gherea had forwarded, Stere denounced protectionism as a "pathetic experiment," the creation of large-scale industry in Romania as a "dream," and the reversals of Western evolution in backward agrarian countries as indicative not simply of a different sequence of evolution, but of an entirely different course whose end point most likely was not, and could not be, industrial capitalism (Stere 1996:95; 108). His central argument to this effect was that, unlike Western colonial powers, Romania lacked both the amount of capital and the external markets for pursuing large-scale industrialization, such that its evolution rather resembled that of Europe's colonies: as in colonial contexts, Western financial capital, "ransacking the world for profitable investment" (Stere 1996:116), acted in Romania as a kind of "vagabond capital," proceeding to proletarianize the local work force in order to subsequently "siphon off abroad the wealth thereby accumulated" (Stere 1996:II7). Whereas, in its country of origin, vagabond capital benefited both capitalists and proletarians, its effects in the periphery in turn transferred the otherwise internal class struggle to the level of a global antagonism between bourgeois and proletarian nations. The notion of "vagabond capital," as Stere conceived it, on the one hand claimed explanatory power for the "bourgeoisification" of the proletariat in England (and for similar beginnings in Germany and the United States), which thus postponed the transition to socialism in those countries (an explanation remarkably resembling world-systems analysis' take on the dampened class struggle in the core, as mentioned above), and, on the other hand, for the "proletarianization" of the entire work force in the exploited economies. In maintaining that "Vagabond capital, the foreign capital of backward countries, is none other than the commercial and finance capital-the antirevolutionary capital - of its country of origin"11 (1996:120), Stere located the causes of macro-

11. Emphasis in the original. 
structural change on a global level, thus seeing the development of underdevelopment as an issue of the entire historical system.

Socialist transformation, he concluded, could no longer be accomplished within one state, but only at the level of a world revolution-a prospect which he rejected as unrealistic. In the absence of the industrial capital giving rise to both the Western bourgeoisie and proletariat, the social structure of peripheral countries did not mirror that of core countries. Likewise, underdevelopment was not the outcome of social polarization, but of the action of a particular kind of capital, producing a particular kind of capitalism based on fiscal exploitation through local foreign agents. Consequently, the peripheral countries' contribution to a world socialist revolution could only take the form of a national struggle against this type of capital, incapable of organizing capitalist production in the countries which it penetrated and responsible for the antirevolutionary tendencies in its countries of origin. An agrarian and parliamentary reform, universal suffrage, a peasant party willing to defend the interests of the rural majority, and the organization of agricultural production into cooperatives on the basis of small and mid-scale peasant holdings, were Stere's specific solutions for a modernization that, for the first time since the beginning of the debates, did not equal Westernization.

Given that this perspective on global class struggle between bourgeois and proletarian nations would only become formalized after World War II within dependency theory (see Emmanuel 1972) and virtually "institutionalized" within world-systems analysis, its emergence in turn-of-the-century Romania in the context of a controversy with orthodox Marxism and of a rejection of the Marxist-liberal philosophy of history based on the theory of forms without substance speaks for the fecundity of a peripheral standpoint in shaping the political imaginary of the system by means of a truly innovative political epistemology.

The Romanian theorists' consistent effort of addressing the concrete and the historical in their politically widely divergent views on social development only goes to show that, since many of the concepts relevant to our analysis of systemic change were coined in and about the core, the potential with which solutions to world-systemic crisis are credited in the long run should be assessed differently depending on the structural location of their origin. Concepts like Maiorescu's "forms without substance," Xenopol's "unequal exchange," Gherea's "semicapitalist" countries and "neoserfdom," as well as Stere's "vagabond capital" all represent attempts to outline specific realities of the modern world- system's periphery for which hegemonic social science, centered around an abstract and universal "society," had no labels. As such, they will be reinvented or independently discovered several times throughout the twentieth century (see Love 1996:175), in precisely those regions-most notably Latin America, but also China and Russia-which faced similar dependency contexts. During the following sequence of imperial control of Eastern Europe, the communist one, these and related theoretical approaches were condemned precisely along the lines of their national dimension, interpreted as a nationalistic and anti-progressivist stance. As a result, Titu Maiorescu's works were banned from publication for their conservatism and alleged anti-progressivism, as were Xenopol's for their liberalism, Gherea's for his reformist stance toward the Marxist dogma, and Stere's - paradoxically — for having opposed Gherea, and, with him, socialdemocracy. If some of their writings were partially recuperated and gradually republished in the 1960s and 1970s, this never occurred in the context of the authors' connection with the theory of forms without substance, whose underlying evolutionism and advocacy of organicity blatantly contradicted the official communist doctrine of revolutionary transformation.

\section{Future Prospects}

As far as the potential political significance of the peasant masses in noncore regions is concerned, current developments prove Stere's one hundred year-old estimate correct. The scope and intensity of protests against neoliberal policies of land alienation, undertaken by NGO networks and social movements in India (Randeria 2003:50) or by the Landless Workers' Movement ${ }^{12}$ in Brazil, and the legal victories thereby achieved attest both to this social category's antisystemic capability and to the above-mentioned importance of acknowledging the long-term structural continuities and recurrent challenges of a global system in which, to some extent, plus ça change, plus c'est la même chose.

However, if history repeating itself entails a reiteration of chances, it simultaneously bespeaks a reiteration of risks. The collapse of communist regimes in Eastern Europe, taken as proof of the ideological bankruptcy of the socialist model, has prompted the proclamation of the "end of history" (Fukuyama 1992), i.e., the end of the search for political alternatives, as well as a corresponding ultraliberal trend toward privatization and anti-statism (Smith et al. 1999:6). In turn, the developmentalist view underlying both socialist and liberal regimes was

12. Movimento dos Trabalhadores Rurais Sem Terra - Brazil's landless workers movement, initiated in 1985 . It is now the largest social movement in Latin America, with an estimated I.5 million members (see http://www.mstbrazil.org) 
replaced by the ideology of globalization (Wallerstein 2005b:323), promoting a withering away of the state to the benefit of the self-regulating global market. For Eastern European societies, agreeing to the terms of this new "civilizing mission" meant being once again defined as "catching up" with the West and embarking on a supposed transition from the Second to the First World, whose conditions-in the form of EU regulations, IMF "structural adjustment" policies and World Bank provisions - are being dictated by the latter. Economically, the parallels with the treatment to which Latin American countries were subjected during the 1950 and 60 in the name of modernization are striking. Politically and epistemologically, what is at stake for those ex-communist countries having long made the bone of contention of Europe's powerful empires is the possibility of a renewed shift of axis ${ }^{13}$ - away from the semiperipheral identity of an Eastern bloc country and toward a yet-to-be-defined position within the "orbit" of the Euro-American core. The fact that this has been characteristic of the entire Eastern European zone since the so-called fall of the Iron Curtain and the beginning of the race for Europeanization becomes evident in the intellectual and political discourses of national elites in Croatia, Slovenia, Poland, Hungary, Bulgaria, and Romania, the common denominator of which is the constant downplaying of their countries' "Easternness" and the corresponding emphasis on their will—indeed, their entitlement-to Westernization, seen as a "return to Europe" (Bakić-Hayden 1995, Lindstrom 2003, Boatcă 2007).

While the political dimension of the core's latest global design-whether promoted as globalization or Europeanization-aptly conceals the double standard that allows a strengthening of core states' apparatus even as it mandates the weakening of peripheral states' sovereignty (Sassen 1996:27), its epistemological component entails the consistent dismissal of state-based policies, government intervention, and national concerns. With the resurgence of Balkanism as part of the Western geopolitical imaginary and the subsequent replacement of the "communist threat" by the "danger of nationalism" in Western media accounts of Eastern Europe, identifying and denouncing nationalism at home therefore became part and parcel of the strategy of political, economic, and intellectual alignment with the European norms embraced by the local political elites. This "anti-state ideological backlash" (Böröcz 1999:200), fuelled on the one hand by

13. The phenomenon that Bădescu has labelled the "shift of peripheral axis" is remarkably similar to the processes that Mitchell Allen (I992) has found to characterize so-called "contested peripheries" in pre-capitalist world-systems. While it cannot be dealt with at length here, Allen's concept of the "contested periphery" might prove rewarding when applied to an analysis of Romania's historical and present case. the delegitimization of (communist) states as agents for prosperity and by neoliberalism's promise of economic bounty on the other, acts in the form of a concerted communist-cum-neoliberal epistemic control that old intellectual circles in dire need of legitimacy, as well as the newly emerged ultra-liberal intellectual and political elites of the region exert on past and present local knowledge production (Boatcă 2006).

The Romanian theory of forms without substance and the decade-long debates on the issue of peripheral development it engendered, gradually restored to public memory in a series of sociological and cultural history studies (Bădescu/Ungheanu 2000, Georgiu 200I, Bădescu 2004), have constituted one of the main targets of the "witch hunt" after dissenters from the ideological hegemony of anti-state discourse in the past 15 years. The intellectual discredit of approaches developed within this framework, once again defined as "nationalist", "anti-progressive", ultimately "Anti-European" on account of running counter to the "liberal-Marxist consensus" underlying the modern worldsystem's linear philosophy of history, has finally led to their political discredit as possible models for social transformation. In the context of a modernization/ globalization theory once again professing the adoption of (political and institutional) forms without (economic and social) substance, Romania is on the one hand equipped with the developmental and antisystemic potential derived from a semiperipheral position, alongside the experience of peripherality and a rich theoretical heritage dealing with it. The chance to reassess and promote old solutions to a recurrent problem in the context of a vacuum of political hegemony is however stunted by the continued epistemic discredit of forms of resistance containing a national component, accordingly denounced as dubious scholarship and political dynamite (see Boatcă 2006).

On the other hand, Eastern Europe's "shift of axis" is paralleled by what has routinely been described as Latin America's "shift to the Left" or "new left axis" in the wake of leftist electoral victories throughout the subcontinent during the past decade. Yet, in spite of echoing the socialist ambitions which the Cuban revolution had instilled in the early dependentistas and raising U.s. fears of regional instability on that account, the new leftward swing and the ensuing open policy of rapprochement with Cuba pursued by Brazil, Argentina, Venezuela, Bolivia, and Uruguay is only part of the story. The increasing political and institutional affirmation of Indigenous social movements in Mexico, Bolivia, Ecuador, and Brazil, the emergence of Afro-Carribbean and Afro-Andean movements, and the gaining momentum of the World Social Forum as an epistemological alternative to neoliberal globalization are part of a process of social and political subject formation that is indicative of a more radical transformation (Mignolo 2005; 2006, Quijano 2004). Thus, the unprecedented impact of the Movimento 
sem Terra in Brazil on the scope of land redistribution and reforms that a peasant movement can mobilize, the Afro movements' claim to epistemic (rather than cultural) rights, and the idea that "there is no global social justice without global cognitive justice" that the World Social Forum in Porto Alegre has proposed as an epistemological alternative to the capitalist monoculture of knowledge (Santos 2004:13) reveal the fact that, today, "the key site of struggle" (Mignolo 2005:I15) between what Immanuel Wallerstein has called "the spirit of Davos" and "the spirit of Porto Alegre" (Wallerstein 2005a:37) is the epistemic realm:

...the worldwide movement against neoliberalism showed its teeth first at Chiapas, then at Seattle in 1999, and subsequently morphed into the World Social Forum, commonly referred to as Porto Alegre.... What we are seeing here is a geopolitical assertion of Latin America in the world-system. It involves pulling away from Western Hemisphere structures and moving toward Latin American structures, one that are also allied with what we used to call Third World structures. The game is scarcely over, and there is certainly no guarantee how it will come out. But Latin@ identity, that is Latin American identity, is at the center of that effort. (Wallerstein 2005a:36f.)

Against this background, rather than a "shift to the Left," and thus toward a transformative politics that stays within the logic of the capitalist world-economy, the current developments in Latin America have recently been described as a "decolonial shift" (Mignolo 2006) that attempts to transcend the Eurocentric notions of Left and Right by placing the emerging social and political agency of indigenous, subaltern and marginalized groups at the center of decision-making processes. Brazil's growing importance in organizing resistance and providing alternatives to the neoliberal trade agenda in the period accompanying the consolidation of the World Social Forum at Porto Alegre, the explicit inclusion of indigenous people's rights in the agenda of the "Bolivarian revolution" in Venezuela, but especially the redistributive economic policies implemented in Bolivia by Evo Morales, the first Indigenous president in South American history, are seen as indicative of a political epistemology that points to an alternative logic. Neither does the World Social Forum embody the internationalism associated with the anti-capitalist politics of the North in the twentieth century (Santos 2004:32), nor is the recent nationalization of Bolivia's oil and gas reserves an instance of a state socialism of a Marxist bent, but these and similar developments in the South represent further stages in a process of decolonization which has been under way for five centuries (Mignolo 2006:94). Their current success is in part due to the unprecedented visibility-in this case, of resistance (Quijano 2002:18) - that a semiperipheral position in the worldsystem hierarchy entails for areas with a long peripheral past.
In the end, rather than a "spiral" in which capitalism and socialism are mutually stimulating (Boswell and Chase-Dunn 2000:I3Iff.), their juxtaposed $\mathrm{s}(\mathrm{w})$ ay in Eastern Europe, alongside their lasting explanatory force as leading categories of the world-system's geoculture as a whole instead gags semiperipheral locations for novel solutions to the world-systemic crisis. The interregnum at which the communist demise once again placed Romania-and with it, the whole of still-semiperipheral Eastern Europe-at the end of the twentieth century might therefore turn out to present an epistemological stake as well: succeeding in claiming definition power for their own designs for social change and world-systemic transformation, alongside corresponding economic alternatives to the current model, could well become the new geohistorical edge deciding this—and other-semiperipheral regions' renewed drift into the periphery.

\section{REFERENCES}

Allen, Mitchell. I992. "The Mechanisms of Underdevelopment. An Ancient Mesopotamian Example." Review I5 (3):453-476.

Arrighi, Giovanni, and Jessica Drangel. 1986. "The Stratification of the WorldEconomy: An Exploration of the Semiperipheral Zone." Review I0:9-74.

Bakić-Hayden, Milica. I995. "Nesting Orientalisms: The Case of Former Yugoslavia." Slavic Review 54 (4):917-93I.

Bădescu, Ilie. 2004. Sincronism european şi cultură critică românească. Cluj Napoca: Ed. Dacia.

Bădescu, Ilie, and Mihai Ungheanu, eds. 2000. Enciclopedia valorilor reprimate. Bucharest: Pro-Humanitate.

Boatcă, Manuela. 2003. From Neoevolutionism to World-Systems Analysis: The Romanian Theory of 'Forms without Substance' in Light of Modern Debates on Social Change. Opladen: Leske + Budrich. 2005. "Peripheral Solutions to Peripheral Development: The Case of Early 2oth Century Romania." Journal of World-Systems Research XI (I):3-26. http://www.jwsr.org

.2006. "Knocking on Europe's Door: Romanian Academia Between Communist Censorship and Western Neglect." South Atlantic Quarterly 105 (3):55I-579.

.2007. "Define and Ruleः The Role of Orientalism in. Re)Colonizing Eastern Europe." Forthcoming in Islam and the Modern Orientalist World-System, edited by Khaldoun Samman and Mazhar Al-Zo'by. Paradigm: Boulder/ London.

Boswell, Terry, and Christopher Chase-Dunn. 2000. The Spiral of Capitalism and Socialism: Toward Global Democracy. Boulder/London: Lynne Riener. 
Böröcz, József. 1999. “From Comprador State to Auctioneer State: Property Change, Realignment and Peripheralization in Post-State-Socialist Central and Eastern Europe." In States and Sovereignty in the Global Economy, edited by David A. Smith, Dorothy J. Solinger, and Steven C. Topik. London \& New York: Routledge.

Burns, Thomas J., Davis L. Byron, and Edward L. Kick. 1997. "Position in the WorldSystem and National Emissions of Greenhouse Gases." Journal of World-Systems Research 3:432-466. http://www.jwsr.org

Chase-Dunn, Christopher. 1988. "Comparing World-Systems: Toward a Theory of Semiperipheral Development." Comparative Civilizations Review 19:29-66. 200I. "World-Systems Theorizing." In Handbook of Sociological Theory, edited by Jonathan Turner. New York: Plenum.

2005. "Social Evolution and the Future of World Society" Journal of World-Systems Research XI, 2, I7I-192. http://www.jwsr.org

Chase-Dunn, Christopher, and Thomas D. Hall. 1997a. Rise and Demise: Comparing World-Systems. Boulder, CO: Westview Press. 1997b. "Ecological Degradation and the Evolution of World-Systems." Journal of World-Systems Research 3:403-431. http://www.jwsr.org

Chirot, Daniel. 1978. "A Romanian Prelude to Contemporary Debates about Development." Review II (I):II5-I23.

Dobrogeanu-Gherea, Constantin. I908a. "Post-scriptum sau Cuvinte uitate." PP. 476-504 in Constantin Dobrogeanu-Gherea, 1976. Opere complete. Vol. 2. Bucharest: Ed. Politică. 1908b. "Un mic răspuns la o mică recenzie." In Constantin DobrogeanuGherea. 1976. Opere complete, vol. 3. Bucharest: Ed. Politică. - 1910. Neoiobăgia. Studiu economico-sociologic al problemei noastre agrare. Bucharest: Socec.

Emmanuel, Arghiri. 1972. Unequal Exchange: A Study of Imperialism of Trade. New York: Monthly Review Press.

Feres Jr., João. 2003. "The History of Counterconcepts: Latin America as an Example." History of Concepts Newsletter 6:14-19.

2005. A bistória do conceito de "Latin América" nos Estados Unidos. Bauru and São Paulo: EDUSC/ANpocs.

Frank, Andre Gunder. 1966. "The Development of Underdevelopment." Montbly Review I8 (4):I7-3I (I):34-59.

. 1992. "Nothing New in the East: No New World Order." Social Justice I9

Fukuyama, Francis. 1992. The End of History and the Last Man. New York: Avon Books.

Georgiu, Grigore. 200I. Identitate şi integrare. De la disjuncție la conjuncție. Bucharest: Institutul de Teorie Socială.

Grosfoguel, Ramón. 2000. "Developmentalism, Modernity and Dependency Theory in Latin America." Nepantla: Views from South I (2):347-372.
Kick, Edward. 1987. "World System Structure, National Development, and the Prospects for a Socialist World Order." In America's Changing Role in the WorldSystem, edited by Terry Boswell and Albert Bergesen. New York: Praeger.

Lindstrom, Nicole. 2003. "Between Europe and the Balkans: Mapping Slovenia and Croatia's 'Return to Europe' in the I99o's." Dialectical Anthropology 27:313-329.

Love, Joseph L. 1996. Crafting the Third World: Theorizing Underdevelopment in Rumania and Brazil. Stanford: Stanford University Press.

Maiorescu, Titu. 1973a. "În contra direcției de astăzi." In Critice by Titu Maiorescu. Bucharest: Minerva.

.1973b. "Direcția nouă." In Critice by Titu Maiorescu. Bucharest: Minerva

Malowist, Marian. 1966. "The Problem of the Inequality of Economic Development in Europe in the Latter Middle Ages." Economic History Review XIX (I):15-28.

Mignolo, Walter. 2000. Local Histories/Global Designs: Coloniality, Subaltern Knowledge, and Border Thinking. Princeton: Princeton University Press.

. 2002. "The Zapatistas's Theoretical Revolution: Its Historical, Ethical, and Political Consequences." Review xxv (3):245-275.

2005. The Idea of Latin America. London/New York: Blackwell. 2006. "Evo Morales en Bolivia: ¿giro a la izquierda o giro descolonial?” In Democracias en desconfianza: Ensayos en sociedad civil y politica en América Latina, edited by José da Cruz. Montevideo: Coscoroba.

Quijano, Aníbal. 2002. "El nuevo imaginario anticapitalista." América Latina en movimiento 35I (xxvI):I4-2I. 2004. "El laberinto de América Latina: ¿Hay otras salidas?" Revista Venezolana de Economia y Ciencias Sociales Io (I):75-97.

Randeria, Shalini. 2003. "Cunning States and Unaccountable International Institutions: Social Movements and the Rights of Local Communities to Common Property Resources." European Journal of Sociology XVI (I):27-60.

Sahlins, Marshall, and Elman R. Service (eds.). 1960. Evolution and Culture. Ann Arbor: University of Michigan Press.

Said, Edward W. 1994. Orientalism. New York: Vintage Books.

Santos, Boaventura de Sousa. 2004. The World Social Forum: A User's Manual. Madison. Retrieved November 2, 2006 http://www.ces.uc.pt/bss/documentos/ fsm eng.pdf.

Sassen, Saskia. 1996. Losing Control? Sovereignty in an Age of Globalization. New York: Columbia University Press.

Schwartzmann, Kathleen C. 2004. "Globalization: The New Mechanism of Dependency." In Globalization, Hegemony \& Power: Antisystemic Movements and the Global System, edited by Thomas Ehrlich Reifer. Boulder and London: Paradigm Publishers.

Smith, David, Dorothy Soliger, and Steven C. Topik (eds.). 1999. States and Sovereignty in the Global Economy. London and New York: Routledge.

Stahl, Henri H. 1978. "Théories de C.D. Gherea sur les lois de la pénétration du capitalisme dans les 'pays retardataires." Review II(I):IOI-II4. 
.1993. "Théories des processus de 'modernisation' des Principautés

Danubiennes et de l'ancien Royaume de Roumanie. I850-1920." Review XVI

(I):85-III.

Stere, Constantin. 1996. Social-democratism sau poporanism? Galați: Porto Franco.

Szlajfer, Henryk. I990. "Editor's Introduction." PP. I-I7 in Economic Nationalism in East-Central Europe and South America 1918-1939, edited by Henryk Szlajfer.

Geneva: Librairie Droz.

1990. "Economic Nationalism of the Peripheries as a Research Problem." PP. 55-I30 in Economic Nationalism in East-Central Europe and South America 1918-1939, edited by Henryk Szlajfer. Geneva: Librairie Droz.

Todorova, Maria. 1997. Imagining the Balkans. New York and Oxford: Oxford University Press.

Trotsky, Leo. 1932. The History of the Russian Revolution. Ann Arbor: University of Michigan Press.

Wallerstein, Immanuel. I99ra. Geopolitics and Geoculture: Essays on the Changing World-System. Cambridge: Cambridge University Press. I99Ib. Unthinking Social Science: The Limits of Nineteenth-Century Paradigms. Cambridge: Polity Press.

Press.

1979. The Capitalist World-Economy. Cambridge: Cambridge University

.2000. "The Rise and Future Demise of the World Capitalist System." PP. 7I-I05 in The Essential Wallerstein. New York: The New Press.

.2005a."Latin@s: What's in a Name?"pp.3I-40 in: Latin@s in the WorldSystem. Decolonization Struggles in the $21^{\text {st }}$ Century U.S. Empire, edited by Ramón Grosfoguel, Nelson Maldonado-Torres, and José David Saldívar. Boulder and London: Paradigm Publishers.

.2005b. "After Developmentalism and Globalization, What?" Social Forces $83(3): 322-336$.

Wolf, Eric. 200I. "The Second Serfdom in Eastern Europe and Latin America." pp. 272-288 in Pathways of Power. Building an Antbropology of the Modern World. Berkeley and Los Angeles: University of California Press.

Xenopol, Alexandru D. I882. "Comerțul exterior al României" pp. 83-I27 in Studii Economice by Alexandru D. Xenopol, 1967. Bucharest: Ed. Academiei Republicii Socialiste România. 